\title{
アパレル産業に関する JIS 用語の概要について
}

$\begin{array}{lll}\text { 石 川 } & \text { 章 } & \text { 一* } \\ \text { 川 端 } & \text { 龍 } & \text { 義** }\end{array}$

\section{1. まえがき}

アパレル産業に関する用語は，衣料品の製造業者 を始め, 販売業者, 検査試験の関倸者, 教育関係者 や一般消費者など, 各方面で基本的に重要なもので ある。

このようなことから, 現在, 次のような JIS が制 定されている.

JIS L 0111-1983 衣料のための身体用語

JIS L 0215-1984 繊維製品用語（衣料）

JIS L 0120-1984 ステッチ形式の分類と表示記 号

JIS L 0121-1984 シームの分類と表示記号

JIS L 0112-1986 衣料の部分・法用語

JIS L 0122-1987 縫製用語

しかしながら,これらのJISについて関係者の力 々への普及が弱く, その理解と活用が不充分である.

前記, JIS の制定の経過と規格内容の概要につい て説明し、アパレル産業及び教育機関を含む関連業 界の標準化や教育用に，一般に広くかつ有効に活用 されることを望むものである.

\section{JIS 制定の経過と内容}

\subsection{JIS L 0111-1983 衣料のための身体用 語}

\section{（1）制定の経過}

身体の基準部位及び寸法に関する用語は，衣料の 設計，製作に関して，工業用にも教育用にも基礎的 に重要な事項である.

従来，これらの身体用語は，身体寸法としても衣
料寸法としても用いられ，両者の区別がなされてい ない用語が相当多く使用されてきた，又，これらに 関する学術用語は制定されておらず，学術的に使用 されてきた用語には，常用漢字表になく，一般の人 には読みにくい漢字が多く使われていた。

工業技術院が昭和53－56年度に行った，衣料のた めの国民の身体計測の結果を衣料サイズ規格に反映 させ，身体寸法のデー夕を活用していくためにも， これらの用語の確立が望まれていた。

工業技術院は昭和 56 年に, 前記, 日本人の体格調 查研究を受託したJIS 衣料サイズ推進協議会（会長 石川章一 東京工業大学名誉教授) に対して原案作 成委託を行った。

同協議会は原案作成委員会を組織し，主として柳 沢委員 (大妻女子大学教授) 提出の原案を基礎とし て慎重審議を行い, 昭和 57 年 2 月に工業技術院に最 終原案を提出, 昭和 57 年 9 月開催の繊維部会に付議 され承認された。

（2）規格の内容

(1)この規格は，衣料のために用いる身体に関す る主な用語について規定しており身体の基準部 位（頭頂点，バックネックポイント，正中線， バストラインなど24種)に関する用語と寸法(身 長, 乳頭の高さ, 胴部横径, 腹囲など66種) に 関する用語に分類している.

(2) 用語の工業標準として常用漢字，仮名使いを 用いて，一般的に分かりやすく読みやすい用語 になっている，例えば，足先点の読み方は“そ くせんてん”ではなく, 聞いても分りやすい“あ しさきてん”にしている.

用語の意味だけでは分かりにくいおそれがあ

*S. Ishikawa, 日本衣料産業研究会議

**T. Kawabata, JIS 衣料サイズ推進協議会事務局 
るので，付罒を添付し用語を示している.

(3) 同一用語が，身体寸法と同時に衣料寸法を意 味するようなことは,できるだけなくしている. 例えば“回り”“丈”などは，できるだけ衣料 寸法の用語とし，身体用語では“囲”“高さ” などが用いられ，雨者の区別を明確にしている.

(4) 胸囲, 胴囲, 腰囲については特に多くの議論 があったが，用語としてはチェスト（男子）， バスト (女子), ウエスト，ヒップを採用して いる.

(5) 体型に関する用語は，明確な表現も困難であ り，その分類の研究も行われていなかったこと などから本規格では掲載されていない.

(6)国際規格との整合性を図るという立場から， ISO 3635-1981 Size designation of clothesDefinitions and body measurement procedure 充分に検討し，なるべくこれらによっており， 同規格に掲載の図を参考図として示している.

(7) 現在審議中の ISO/DIS 8559 Garment construction of anthropomeric surveys-Body dimensionsについても，本規格との整合性をは かるため，我国の意見をISO 事務局に提出し ている

\subsection{JIS L 0215-1984 維維製品用語（衣料）}

\section{（1）制定の経過}

従来，繊維製品に関する用語規格として，次の 4 規格があった。

JIS L 0212-1966 繊維二次製品用語

JIS L 0211-1963 繊維用語（メリヤス部門）

JIS L 0213-1970 䋐維雑品用語

JIS L 0214-1973 瀻維用語（レース部門）

このうち, 前 2 規格は制定以来およそ 20 年を経過 し，その間に新しい製品が増加して追加を要するも のが多くあること，メリヤス用語の中には二次製品 と重複するものが多いことなど，各規格間の分類， 内容等に整理，調整すべき点が生じてきた．その結 果, 繊維二次製品用語は，衣料とその他（寝具, 床 敷物等）に2 分割しそれぞれ改正增補を行うことに なり，工業技術院は昭和57年度に㵶維工業標準研究 会 (会長 小林正 日本化学䋐維検査協会理事長) に原案作成を委託した。

同研究会では，原案作成委員会（委員产 石川章 一）を組織し検討審議を行い，昭和58年 2 月原案を 作成し報告, 昭和 59 年 3 月繊維用語専門委員会及び
繊維部会の審議を経て承認された.

\section{（2）規格の内容}

(1)この規格は, 繊維製品のうち主として衣料に 関する主な用語について規定しており，分類に ついては一般の項目に総称的な用語並びに年齢 や男女に関係なく用いられるものがまとめら れ，その他，男子用外衣，女子用外衣，七一夕。 シャツ類, 乳幼览用衣服, 和服及び和装品, 肌 着, ファンデーション, 寝衣, 帽子, 手袋, 靴 下など12項目に分類されている。

(2) 前項の通り大きく分類した中の各用語は，現 在，生活の中で使用されているものをできるだ け網羅している. 又, 用字は常用漢字を用い, それがないものは平仮名を用いるようにし，フ アンデーションのような外来語には，片仮名が 用いられている．和服の場合もこれによってい る.

(3) 従来の用語にあって, 同一のものを表す別の 用語については，呼称が変化し新しい用語が定 着したものは，新しい用語に改めている.

例えば，続き服，スキーズボン，䏫あてズボ ン，ディバイデットスカートを，それぞれ，つ なぎ服，スキーパンツ，サロペット，キュロッ トスカートに改めた。 セータ・シャツ類では, 開きんシャツをオープンシャツに改め，アロ八 シャツ, ニットシャツ, Tシャツ, タンクトッ プなどが追加された。

(4) 乳幼児用衣服では, ベビー胴着, 寝冷えしら ずなどを削除し，カバーオール，オーバオール， ママコートを追加している.

(5) 和服及び和装品は，大裁ち，小裁ちを実際に 合わせて, 本裁ち, 四つ裁ち，一つ身裁ちと改 めた。

又, 和服用語には, 模様からくる名称, そで の形からついた名称など伝統的な用語も多い が，現在ほとんど用いられていない舟底そで， もじりそで，ひろそでなどは削除した.

(6) 帽子は，現行57品目のものを“……するとき かぶる帽子”という意味のものはできるだけ用 語から削除し，42品目が決められた。

\subsection{JIS L 0120-1984 ステッチ形式の分類 と表示記号}

\section{（1）制定の経過}

我国には“ステッチ”に対する適切な用語がなか 
った，又，その種類が多いにもかかわらず，その用 語も充分確立されていなかった。

従来, ○○縫いという用語がステッチとシームと の区別なく多く使われてきた．ISO（国際標準化機 構）では，1981 年 12 月に ISO 4915 Stitch types-c lassification and terminology が制定された。なお， この作案は, ISO/TC 38/SC 10 (Stitches, seams and stitching's）（事務局 BSI一英国規格協会）で行われ た.

工業技術院はこれを踏まえて, 昭和57年度に日本
工業ミシン協会 (会長 美馬隆一 ペガサスミシン 製造(侏) 社長) に原案作成を委託した。同協会では， 原案作成委員会を組織し，関連の“シームの分類と 記号”の原案と対忍しながら検討審議を行い, 昭和 58 年 3 月原案を作成し報告, 日本工業標準調查会シ 一ム・ステッチ専門委員会で審議された後, 昭和 59 年 3 月の繊維部会で議決された.

\section{(2) 規格の内容}

(1)この規格は，手縫い及び機械縫いに用いられ る種々のステッチ形式の分類と表示記号につい

\begin{tabular}{|c|c|c|}
\hline 用 & 味 & (参考)対応英語 \\
\hline ステッチ & $\begin{array}{l}\text { 系又は系のループが, 自系ルーピング, 他糸ルーピング, 他系レーシング } \\
\text { し, 又は, 布の中に入り, 若しくは, 布を通り抜けてできる形態の一単位. }\end{array}$ & stich \\
\hline 自糸ルーピング & $\begin{array}{l}\text { 糸の一つのループが, 同じ系の他のルー } \\
\text { プを通り抜けること. }\end{array}$ & intralooping \\
\hline 他糸ルーピング & $\begin{array}{l}\text { 糹の一つのループが, 他の糸のループを } \\
\text { 通り抜けること. }\end{array}$ & interlooping \\
\hline 他糸レーシング & $\begin{array}{l}\text { 糸が, 他の糸, 又は, 他の糸のループと } \\
\text { 交差又は通り抜けること. }\end{array}$ & interlacing \\
\hline ステッチ形式 & $\begin{array}{l}\text { 布に対して, ステッチが方向性をもって } \\
\text { 繰り返される集合. }\end{array}$ & stitch type \\
\hline 糸のグループ & $\begin{array}{l}\text { 例えば, 針系のグループ, 若しくは, ルーパ糸のグループという同じ機能 } \\
\text { をもつ幾本かの糸の集まり. }\end{array}$ & group of threads \\
\hline 針系 & 針によって布の中に入り, 若しくは, 布を通り拢ける系. & needle thread \\
\hline ボビン糸 & 針系と布の中, 若しくは, 布面で他系レーシングする系。 & bobbin thread \\
\hline ルーパ系 & $\begin{array}{l}\text { ルーパによって, 布面若しくは, 布の端部で, もう一つのループと他系ル } \\
\text { ーピング, 又は, 自系ルーピングする系. }\end{array}$ & looper thread \\
\hline 飾 り 系 & $\begin{array}{l}\text { 布の表面で, 飾りを目的として, 針系の間を渡り, 針系と他糸ルーピング } \\
\text { やる系. }\end{array}$ & cover thread \\
\hline
\end{tabular}

備考ここの規格で用いる布という用語は，すべての縫製素材の意味である。 
て，ISO 4915に規定しているすべてのステッチ 形式を規定している，従来からステッチ及びス テッチ形式の用語が規定されておらず，適当に 使用されてきたが，この規格ではステッチを始 め, 主な用語の意味を前表通り定義するなど全 く新しい形の規格として制定された.

(2) 用語の意味で, ISO 4915では, intralooping, interlooping, interlacing という用語が使われて いる.これは新しい概念の用語なので片仮名に することも検討したが,なじみにくいことから， 自系（じし）ルーピング，他系（たし）ルーピ ング，他系（たし）レーシングとなった，又， ISO 4915にはなかったが，針糸，ボビン系，ル 一パ系, 飾り系については, 説明の中に使われ るので, 本規格で新たに定義している.

(3) ステッチ形式の分類は, ISO 4915に準拠して
100 から 600 までの 6 種類にクラス分類してい る.これらに対し，我国における慣用に即して， JIS B 9070工業用ミシンの分類に対する用語と 表示記号に規定する用語を併記している.

(4) ステッチ形式の表示は，3けたの数值表示に なっている.これは仕様書やコンピュー夕処理 等，実際に使用する上で極めて便利である.

(5) ステッチ形式の図示方向は, すべて ISO 4915と同一になっている.

例として, 本縫いの場合の表示記号と図及び 説明の一部を図 3 に示す.

このように本縫いといっても，301から327ま で27種類もあるので分かりにくかったが，例示 のように301，303のステッチ形式というょうに 表示記号で示すことができる.

(6) クラス分類として，100は単環縫い，200は手

付 图 3 クラス300の細分類

\begin{tabular}{|c|c|c|}
\hline 表示記号 & 困 & 及 び 説 明 \\
\hline 301 & & 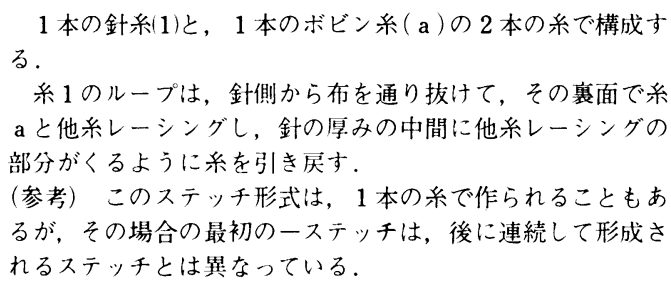 \\
\hline 302 & & $\begin{array}{l}2 \text { 本の針系 }(1 \text { 及び } 2) \text { と } 1 \text { 本のボビン系 }(\mathrm{a}) \text { ) } 3 \text { 本の系で } \\
\text { 構成する. } \\
\text { 系 } 1 \text { 及び } 2 \text { のループは, 針側から布を通り抜けて, その裹 } \\
\text { 面で系 } \mathrm{a} \text { と他糸レーシングする. }\end{array}$ \\
\hline 303 & & $\begin{array}{l}3 \text { 本の針系 }(1,2 \text { 及び } 3) \text { と } 1 \text { 本のボビン系 }(\mathrm{a}) \text { の } 4 \text { 本の } \\
\text { 系で構成する. } \\
\quad \text { 糸 } 1,2 \text { 及び } 3 \text { のループは, 針側から布を通り抜けて, そ } \\
\text { の裏面で系 } \mathrm{a} \text { と他系レーシングする. }\end{array}$ \\
\hline 304 & & $\begin{array}{l}\text { このステッチ形式は, 301が図のようなジグザ } \\
\text { グ模様を形成したものである. }\end{array}$ \\
\hline
\end{tabular}


図4 クラス 400 の細分類

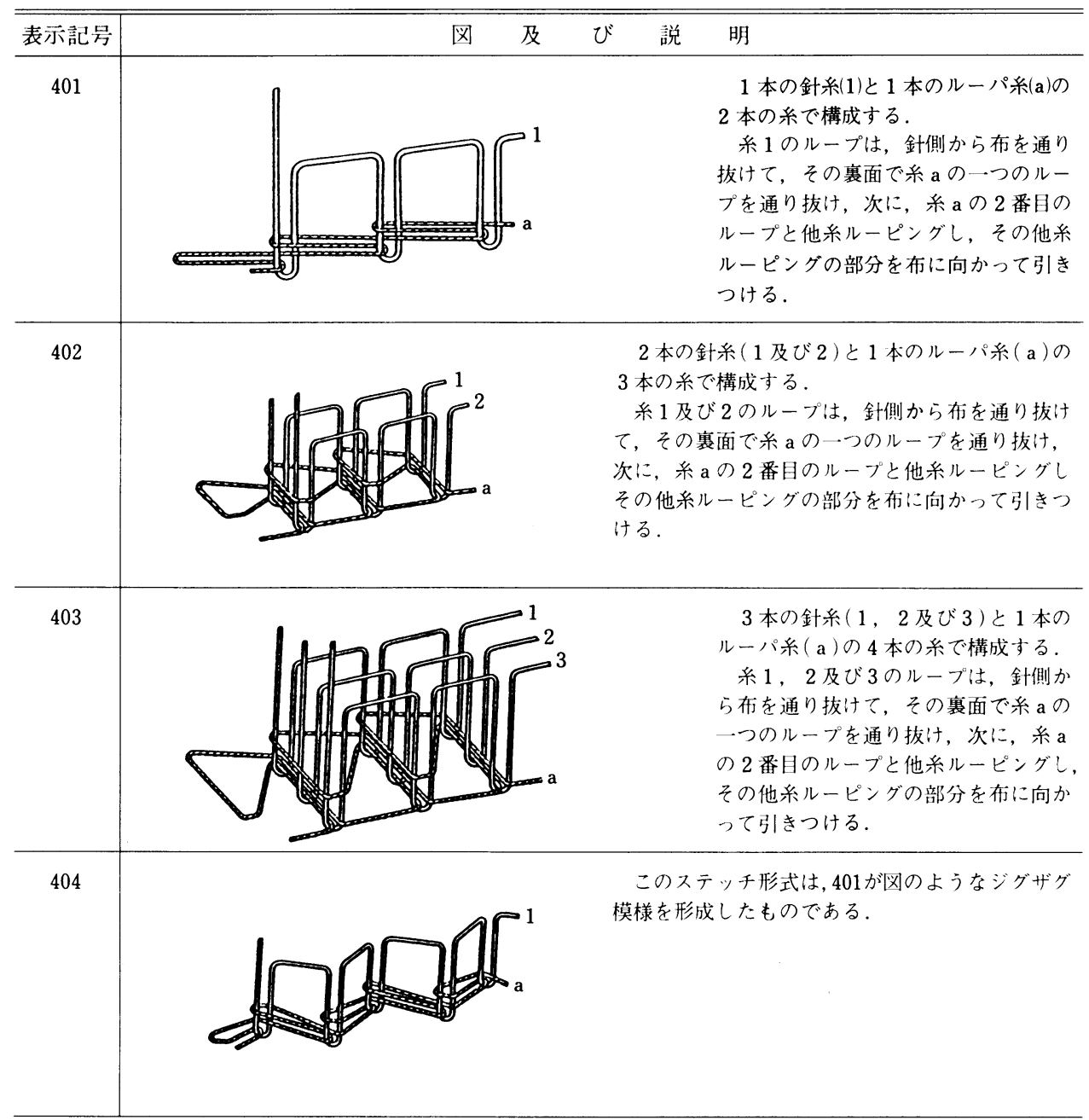

縫い，300は本縫い，400は一重環縫いであるが， 環縫いの一部を図 4 .

\subsection{JIS L 0121-1984 シームの分類と表示 記号}

\section{（1）制定の経過}

我国には“シーム”に対する適切な用語がなく， 又，その種類は非常に多いが，これに対する用語も 確立しておらず充分なものがなかった。

ISO では，1982年 8 月に ISO 4916 Textiles-Seam Types-classification and Terminology が制定され た.

なお,この作案は, ISO/TC 38/SC 10で行われた.

工業技術院はこれを踏まえ，昭和57年度に日本衣 料産業研究会議（会長 石川章一）に原案作成を委
託した，同会では，原案作成委員会を組織し，検討 審議の結果, 昭和 58 年 3 月に原案を作成し報告, 日 本工業標準調查会シーム・ステッチ専門委員会の場 で，ステッチ形式の分類と表示記号の原案とともに 審議され, 昭和 59 年 3 月の繊維部会で議決された。

\section{(2) 規格の内容}

(1) 本規格は，ステッチを用いたシームの分類と 表示記号について定めた規格で，ISO 4916に基 づいて作成されたものである.表題のシームは, 我国にシームに対する的確な用語がないこと や，ISO 4916の趣旨をゆがめないことから，原 語のシームをそのまま採用している，又，ISO 4916の内容を検討した結果，その内容を的確に 表現するため，表題を“シームの分類と表示記 号”とした，本規格において，シームとは 1 枚 
又は数枚の布にステッチを連続的に施したもの をいう，と定義している.

(2) 本規格は，ISO 4916に規定しているすべての シームについて，その分類方法と表示記号を規 定している. ISO 4916は適用対象をステッチド シーム (stitched seams) として明確にしている. 従って，ステッチを施さないで接着や融着など によってシームとすることもできるが，本規格 の対象になっていない，しかし，本規格の内容 は適用対象外のシームにとっても技術的に参考 になるところが多い。

(3) 多種にわたるシームをどう分類するかは, 縫 製技術上の大きな問題といえるものである，適 切な分類がなされていないと, 将来種類の増加 に伴って混乱を招くことにもなりかねない. ISO 4916は，この点を踏まえた上で，8クラス に分類し，かつ表示記号として 5 けたの数值的 表現を採用している.

(4) シームの分類に関するこの規格の分かりにく さは, 慣用語や縫製の日常的思考から離れて, より網羅的, 包括的な表現や思考に基づいて分 類を行ったためと考えられる. 又, シームのク ラス分類において，それぞれのクラスの特徴の 説明がなされているが，文章だけでは分かりに くい面もあるので, 図を示して分かりやすくし てある。

(5) 1〜8のクラスごとにシームを細分類し，具 体的に図で示され, 表示記号が示されている.

(6) シームの表示方法及び四示方法については, すべて ISO 4916に準拠しており，ステッチの 表示記号を付記することになっている．これら について付図により示され，表示記号と対応し て素材構成図で282種針の位㯰図で542種が示さ れている.

次にクラス 1 及びクラス 3 の例を示す.

(7) JIS L 0120 (ステッチ形式の分類と表示記号) に規定するステッチ形式の表示記号を併記する と縫製仕様書などの指示を的確・簡略化できる ことになる。この場合はシームの表示記号の後 に斜めの線を入れて表示する.
例

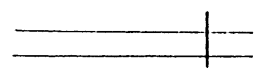

$1.01 .01 / 301$
付図1 クラス 1 の細分類

\begin{tabular}{|c|c|c|}
\hline 布 の 構 成 & 針の位置 & 表示記号 \\
\hline 1.01 & 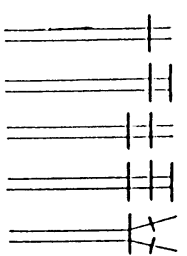 & $\begin{array}{l}1.01 .01 \\
1.01 .02 \\
1.01 .03 \\
1.01 .04 \\
1.01 .05\end{array}$ \\
\hline & $\begin{array}{l}1 \\
=1\end{array}$ & $\begin{array}{l}1.02 .01 \\
1.02 .02\end{array}$ \\
\hline & $\neq$ & 1.02 .01 \\
\hline
\end{tabular}

付 图 3 クラス 3 の細分類

\begin{tabular}{|c|c|c|}
\hline 布 の 構 成 & 針の位置 & 表示記号 \\
\hline 3.07 & $\notin$ & 3.07 .01 \\
\hline 3.08 & 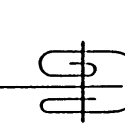 & 3.00 .01 \\
\hline & $\notin$ & 3.09 .01 \\
\hline
\end{tabular}

\subsection{JIS L 0112-1986 衣料の部分・寸法用} 語

\section{（1）制定の経過}

衣料の部分の名称及び寸法の用語については, 業 界・教育界などで重要であるにもかかわらず, 従来, 業界ではそれぞれの場で適当に使用され，それらの 収集, 整理, 統一がされていなかった.

1974年，AEIH（欧州アパレル産業協会）が刊行 した, Glossary of garment designation (A 4 判: 119ページ）は，メンズアウタウエア，ウーメンズ アウタウエア，メンズシャツ，ランジェリー，作業 服などに分類され，その代表的なものについて図を 
示し, 各部分に番号を付け，これに対応する英，仏， 独，伊の 4 か国語による用語を掲載したものである (ただし，寸法用語については記載がない).

この本が我国に紹介されると，产学界でもその必 要性を望まれていたため, 同様な規格作成が必要で あるという機運が高まった。

このような情勢を受けて，工業技術院は，昭和57 年度にJIS 衣料サイズ推進協議会 (会長 石川章一) に原案作成を委託した。同会では業界, 教育界, 検 査機関などの専門家による原案作成委員会を組織 し, 慎重に検討審議を行い原案を作成し, 昭和58年 2 月工業技術院に報告し, 繊維用語専門委員会及び 昭和60年10月の繊維部会の審議を経て議決された。

\section{(2) 規格の内容}

(1) 経過で述べた AEIH 刊行書の日本語版的なも のを作成する予定で規格作成が進められたが， 着用区分や服種分類による用語の共通語が多く あることから，一般衣料，その他，肌着，手袋， 靴下，帽子なども対象とした分類に従って，主 な用語の収集，整理・統一が図られている。

(2) 本規格の分類(1)コート，上衣，ワンピースな どは上半身又は全身用外衣であり，(2)スカート， スラックスは下半身用外衣であるが，各衣料と も着用者対象別や男女別を考えず共通用語とし ている.

(3) (1)コート，上衣，ワンピースなどは衣料の主 要なもので，用語も多いので，身ごろ，えり， そで，ポケットに細分類されて㧍り，肌着，フ アンデーション, 手袋, 靴下, 帽子などは衣料 の種類が違い，製造や販売の分野も異なってい るので別分類とした．用語中には共通のものも あるが，内容が違うので統一しないで慣例に従 ってまとめられている.

(4) 身体寸法用語と衣料寸法用語との区別を明確 にする目的で，例えば，胸囲は身体寸法用語と し，胸回りを衣料寸法用語とし，衣料のある部 分の長さには“丈”の語を使用している.

又，身体寸法用語である肩幅，背肩幅と区別 するため，肩部幅，両肩幅という新用熟を採用 している.

（5) 寸法の用語は，実際に検査などを行う場合に は, 測定方法をより具体的に定める必要がある. 本規格では，検査方法に関する用語と切離して まとめられている.

(6) 用語の意味だけでは分かりにくいものについ
ては，付図によって分かりやすくしている．

\subsection{JIS L 0122-1987 縫製用語}

\section{（1）制定の経過}

アパレル産業に関する用語の JIS は, 前述の $5 つ$ の JIS が制定されてきた。しかしながら縫製作業に 関する用語規格が制定されていなかった。

工業技術院は昭和59年度に，その原案作成を日本 衣料产業研究会議（会長 石川章一）に委託した。

一方, 通産省工業技術院が昭和57年から実施して いる大型プロジェクト“自動縫製システムの技術開 発”は，アパレル生産技術の画期的な発展を目的と しているが，これには各方面の最新技術を結集する 必要があり, アパレル業界, 桻製機器業界のみなら ず，電機業界などの参画をもって推進されてきた. そのため，すべての分野の人が理解でき，活用でき る標準化された縫製用語が必要となってきた.

このような観点から，自動縫製システム技術研究 組合は，縫製用語の作成を日本衣料産業研究会議に 依頼し，同会では縫製用語調査委員会を組織し，従 来の JIS や防衛庁規格（同会が原案作成）などを収 集整理し，又，各企業で使用している用語の抽出整 理も併せて行い，作業工程別に用語を分類した“自 動縫製システムに関する用語”を作成し，昭和59年 12月依頼先に提出した

この用語集を基礎として，さらに検討審議を行い 原案を作成し，工業技術院に提出，昭和 62 年 3 月開 催の瀻維部会に付議され承認された。

\section{（2）規格の内容}

(1) 本規格は，衣料の縫製に関する主な用語，特 に作業に関する用語を中心として規定してい る．縫製機械，特にミシンについてはISO/TC 148においてミシンの分類について検討中であ ること等から，本規格では除外している.

又，ステッチ及びシームについては，それら の分類と表示記号が ISO 規格に対忍して JIS L 0120及び JIS L 0121 （前掲参照）が定められて いるので，これらも除外し，通常使用されてい る日本語の主なものについて用語を引用し，表 示記号との対応をしている.

(2) 用語の分類については，次の通り分類してい る.

（）パターン・・パターンの種類を示すとと もにグレーティングなどの 作業用語をあげている。 
・作図に関する用語では, 作 罒にあたって考慮すべき事 項の用語をあげている.

○縫製準備工程生地の受入れ・延反・裁断 に3 分類し, 必要な用語を 规定している.

() ステッチ

○シーム

(9)プレス

○縫製システム

(ㄷ) 点

○副資材関連
主なものについて JIS L 0120を引用し，対伈する表 示記号を付加している.

目的による縫い・裁ち目の 始末・まつり刺し等・その 他に 4 分類し, 表示記号を 付加している.

一般的な作業に関する用語 について規定している.

一般的なシステムに関する 用語を規定し，企業で開発 しているシステム名称は除 外している.

衣料品にみられる縫製の欠 点に関する用語を規定して いる.

裏, しん, ボタン, テープ などの副資材や総裏など洋 服の仕立て方の用語などを この分類で規定している.
○和服の縫製用語 和服の縫製に関する用語 は, いわゆる和裁の教科書 の用語統一に重要である. 一般の縫製用語と共通のも のもあるが, 意味の違う場 合もあり，独特の用語とと もに一括して付属書として まとめてある。

衣料の欠点などの用語は, 内需品はもちろん, 輸 出入品の検査においても重要である. 衣料の部分・ 寸法をも含む衣料品の検査方法の用語の統一確立 は, 重要な問題として残されている.

\section{3.おわりに}

近年，アパレル工業は，ハイテク，コンピュータ 及び通信技術の伸展に伴って, CAD・CAM や生産 管理，販売管理などのシステム化が普及し，従来の 縫製仕様書などの指示方法では不充分な点が多くな ってきた.そのようなことから縫製用語の標準化と ともに, パターンメーキングの表示記号の統一が強 く要望されている．工業技術院では，昭和63年度に 日本衣料産業研究会議にJIS L 0110 (被服製図通則 —1977）の見直し改正を委託して, 衣料のパターン メーキング表示記号（案）の整理確立をはかること にしている.

\section{Information}

\section{メイトサイエンス(姝)新社屋に移転}

メイトサイエンス侏新社屋完成に伴い，12月15日より 下記に移転。

京都市山科区勧修寺本堂山町1-1，TEL。075-593-5886。

\section{平野金属(怢社名変更}

平野金属(制は 1 月 1 日付で社名を(侏)ヒラノテクシード に変更. 新社長として中川久明氏が就任.

\section{村田機械(怢社名変更}

村田機械(秼)は 6 月 1 日付で社名を(株)ムラ夕（英文 MURATA LTD.) に変更.

又, 1 月 16 日に開催される第 7 回全国都道府県対抗女 子駅伝競走大会に協賛することも決定した.

\section{鐘紡百年史刊行}

このほど創立100周年を迎えられた鐘紡侏はこれを記 念して「鐘紡百年史」を刊行した。

本書は1,086頁を 6 編 65 章及び資料編と年表に分け, 創業期, 武藤山治時代, 津田信吾時代, 武藤絲治時代, 第 1 世紀の仕上時代, 鐘紡第 2 世紀への出発等をそれぞ れ膨大な資料と写真を駆使して編さんされており, 資料 の収集とまとめに多大な努力を伺わせている. 